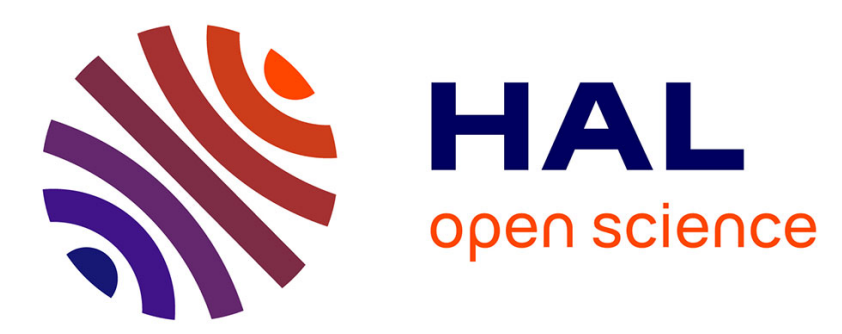

\title{
FHKL- a program to compute rocking curves and crystallographic data of interest for the dynamical theory of X-rays
}

Alain Soyer

\section{- To cite this version:}

Alain Soyer. FHKL- a program to compute rocking curves and crystallographic data of interest for the dynamical theory of X-rays. Journal of Applied Crystallography, 1995, 28 (2), pp.244. 10.1107/S0021889894013397 . hal-01214846

\author{
HAL Id: hal-01214846 \\ https://hal.science/hal-01214846
}

Submitted on 17 Nov 2015

HAL is a multi-disciplinary open access archive for the deposit and dissemination of scientific research documents, whether they are published or not. The documents may come from teaching and research institutions in France or abroad, or from public or private research centers.
L'archive ouverte pluridisciplinaire HAL, est destinée au dépôt et à la diffusion de documents scientifiques de niveau recherche, publiés ou non, émanant des établissements d'enseignement et de recherche français ou étrangers, des laboratoires publics ou privés. 


\section{Computer Program Abstracts}

The category Computer Program Abstracts provides a rapid means of communicating up-to-date information conceming both new programs or systems and significam updates to existing ones. Following normal submission, a Computer Program Abstract will be reviewed by one or two members of the $1 \mathrm{UCr}$ Commission on Crystallographic Computing. It should not exceed 500 words in length and should follow the standard format given on page 189 of the June 1985 issue of the Journal [J. Appl. Cryst. (1985). 18 189-190].

J. Appl. Cryst. (1995). 28, 244

FHKL - a program to compute rocking curves and crystallographic data of interest for the dynamical theory of X-rays. By ALAIN SOYER, Laboratoire de Minéralogie-Cristallographie, Unité associée au CNRS 09, Université Paris 6 et Paris 7, Tour 16, Case 115, 4 place Jussieu, 75252 Paris CEDEX 05, France

(Received 5 September 1994; accepted 21 November 1994)

The crystallographic problem: Crystallographers working in fields such as topography or monochromator design with a conventional $X$-ray source or, more often nowadays, with a synchrotron beam need to compute crystal characteristics: dielectric susceptibilities ) (via structure factors), absorption coefficients $\mu / \rho$ and crystal rocking curves. These computations must be performed to a good precision, taking into account dispersion correction $\left(f^{\prime}\right.$ and $\left.f^{\prime \prime}\right)$, polarization and the dynamical theory for rocking curves.

People generally use a set of rather inconvenient heterogeneous programs for these computations which are not always very user-friendly.

Method of solution: FHKL is a very easy to use menu-driven program: the user enters data and chooses options by clicking on buttons or moving sliders with a mouse inside the $X$-window graphical interface. The program needs only one data file containing information about the atoms of the asymmetric unit of the crystal.

FHKL may perform the following tasks:

(a) Compute structure factors $F_{h k l}$, dielectric susceptibilities $\backslash h k l$ and absorption coefficients $\mu / \rho$ for a given wavelength $\lambda$ and a range of $h k l$ reflexions or for a fixed $h k l$ in a given energy range. The atomic scattering factors $f$ are interpolated by the program with data from International Tables for $X$-ray Crystallography (1974). The dispersion corrections $f^{\prime}$ and $f^{\prime \prime}$ may be calculated either by a program due to Cromer \& Liberman (1970), which is included in FHKL, or from data by Henke, Gullikson \& Davis (1993) as the user wishes. Thermal agitation (isotropic or anisotropic) may also be taken into account.

(b) Draw curves of $f$ versus $\sin (\theta) / \lambda$, $f^{\prime}$ and $f^{\prime \prime}$ versus energy or $\mu / \rho$ versus energy.

(c) Compute and draw crystal rocking curves in reflexion and transmission cases, taking into account perpendicular or parallel polarization.

(d) Perform operations on rocking curves: addition or multiplication by a constant, addition, correlation or convolution of two curves.

Software environment: FHKL is designed for Unix workstations. The main program is written in C but some subroutines involving calculations with complex numbers are written in Fortran. An X-window system and OSF-Motif widgets (Xm library) are required for the graphic interface.

Hardware environment: The program has been developed on an IBM RS6000/560 workstation. It also runs on many other Unix computers: it has been compiled successfully on a HewlettPackard 9000/735, a Silicon-Graphics Indigo, a Sun-Sparc 4/40 ipc and a PC486 running with Linux. The usual $X$-window display is necessary.

The memory size of FHKL depends on the maximum number of atoms in the crystal cell; for 1000 atoms, a memory of about 6 Mbytes is needed.

Program specification: Note that FHKL is usually used for small crystal structures and is not optimized for the calculation of a large number of structure factors in the case of macromolecular structures.

Typical run times for normal utilization are of the order of a few seconds CPU, but in some rare cases it may reach $10 \mathrm{~min}$.

The volume of the source code is estimated as 12000 lines (including comments) for the $\mathrm{C}$ part and 1500 lines for the Fortran subroutines.

Documentation: Documentation of about 900 lines describes the program use and the installation procedure. It is available in the form of an ASCII file or a PostScript file.

Availability: This program is available on request to the author: soyer@Imcp.jussieu.fr. The distribution includes all source codes and documentation and is available by e-mail or $\mathrm{ftp}$. The distribution is free of charge to the research and teaching community.

Keywords: Structure factor, dielectric susceptibility, rocking curve.
The author thanks Don T. Cromer for providing his program to compute the dispersion corrections and E. M. Gullikson for his data files.

\section{References}

Cromer, D. T. \& Liberman, D. (1970). J. Chem. Phys. 53, 1891-1898.

Henke, B. L., Gullikson, E. M. \& Davis, J. C. (1993). At. Data Nucl. Data Tables, 54, 181-342.

International Tables for $X$-ray Crystallography (1974). Vol. IV, ch. 2.2, pp.

71-147. (Present distributor Kluwer Academic Publishers, Dordrecht.) 